\title{
MANAJEMEN RISIKO PADA BANK SYARIAH
}

\author{
Afriyeni, Romi Susanto \\ Akademi Keuangan dan Perbankan Padang \\ afriyeni@akbpstie.ac.id
}

\begin{abstract}
Research and experience over the last two decades has resulted in a deep understanding of issues relating to risk management and the principles of a well established risk faced by management. The company managers are increasingly recognizing the importance of risk management. In the context of risk management, the guidelines were implemented over the years, made only for conventional banks. Whereas players in the world and national banking business not only conventional banks, but has also been enlivened by banks with Islamic principles that number continues to increase from year to year. This paper gives an overview of how risk management in Islamic banking. In general, the risks faced by Islamic banking can be classified into two major parts. Ie the same risks faced by conventional banks and the risk that is unique because it must follow the principles of sharia. Credit risk, market risk, benchmark risk, operational risk, liquidity risk, and legal risk, Islamic banks must be faced. But, because they have to abide by the rules of Sharia, the risks faced by Islamic banks had to be different.
\end{abstract}

Keyword: risk management, Islamic banks

\section{Pendahuluan}

Sepanjang tiga dekade terakhir, pertumbuhan dan perkembangan lembaga perbankan syariah mengalami kemajuan yang sangat pesat, baik di dunia internasional maupun di Indonesia. Konsep perbankan dan keuangan Islam yang pada mulanya di tahun 1970-an hanya merupakan diskusi teoritis, kini telah menjadi realitas faktual yang mencengangkan banyak kalangan.

Pada era modern ini, perbankan syariah telah menjadi fenomena global, termasuk di negara-negara yang tidak berpenduduk mayoritas muslim. Berdasarkan prediksi McKinsey tahun 2008, total aset pasar perbankan syariah global pada tahun 2006 mencapai 0,75 miliar dolar AS. Diperkirakan pada tahun 2010 total aset mencapai satu miliar dolar AS. Tingkat pertumbuhan 100 bank syariah terbesar di dunia mencapai 27 persen per tahun dibandingkan dengan tingkat pertumbuhan 100 bank konvensional terbesar yang hanya mencapai 19 persen per tahun.

Di Indonesia, pertumbuhan dan perkembangan perbankan syariah juga tumbuh makin pesat. Krisis keuangan global di satu sisi telah membawa hikmah bagi perkembangan perbankan syariah. Masyarakat dunia, para pakar dan pengambil kebijakan ekonomi, tidak saja melirik tetapi lebih dari itu mereka ingin menerapkan konsep syariah secara serius.

Disisi lain terdapat kecenderungan perkembangan sistem pencatatan, matematika keuangan dan inovasi teknik manajemen risiko yang tidak dapat diprediksi. Perkembangan tersebut disinyalir akan semakin menambah tantangan yang dihadapi oleh perbankan syariah, terutama dengan masuknya lembaga keuangan konvensional yang juga menawarkan produk-produk keuangan syariah.

Selain itu risiko menghadapi sistem keuangan global bukanlah kesalahan tentang kemampuan menciptakan laba, tetapi yang lebih penting adalah kehilangan kepercayaan dan kredibiliatas tentang bagaimana operasional kerjanya. Oleh karena itu perbankan syariah perlu membekali diri dengan kemampuan manajemen sistem operasi yang mutakhir untuk menyikapi perubahan lingkungan tersebut. Salah satu faktor utama 
yang dapat menentukan kesinambungan dan pertumbuhan industri perbankan syariah adalah, seberapa intens lembaga ini dapat mengelola risiko yang muncul dari layanan keuangan syariah yang diberikan.

Bentuk resiko yang dihadapi oleh institusi keuangan juga berubah. Kalau dalam dua dekade yang lalu, institusi keuangan menghadapi resiko kredit dan pasar, maka institusi keuangan sekarang dihadapkan pada resiko baru dan lebih banyak. Ada beberapa faktor yang menjadi penyebabnya, diantaranya adalah:

1. Inovasi keuangan: inovasi keuangan dan perkembangan yang cepat di pasar derivatif telah meningkatkan kompleksitas manajemen institusi keuangan. Produk-produk inovatif telah muncul baik pada neraca keseimbangan dan produk baru, telah memunculkan profil pendapatan dan resikonya yang mempengaruhi profil resiko dari institusi.

2. Perubahan bisnis perbankan: ada perubahan permanen dalam bisnis perbankan tradisional, sebagai hasil dimana bisnis telah bergerak dari bisnis pemberian pinjaman tradisional kepada aktivitas pemberian pinjaman yang lebih kompleks.

3. Peningkatan kompetisi: kompetisi diperbankan telah meningkat, membuat bankbank kecil sulit untuk bertahan. Bank-bank berskala kecil tidak mampu untuk berkompetisi karena meningkatnya biaya bisnis dan tingginya biaya manajemen resiko.

4. Lingkungan peraturan: didalam krisis keuangan, dan krisis utang Dunia Ketiga pada tahun 1980an hingga krisis di Asia Timur pada tahun 1990an, terjadi kesadaran lebih besar akan kebutuhan peraturan dan pengawasan institusi keuangan.

5. penguapan pasar yang meningkat: institusi keuangan pertama kali menyadari pentingnya manajemen resiko setelah kegagalan sistem Bretton Woods atas tarif pertukaran tetap, yang menimbulkan penguapan signifikan dalam tarif pertukaran asing dan pasar suku bunga. Sejak saat itu, penguapan dipasar dan permintaan akan produk manajemen resiko telah menjadi bentuk permanen dari pasar.

Dalam perkembangannya, hal ini telah meningkatkan kebutuhan akan pengukuran, manajemen, dan pengendalian resiko. Kerangka komprehensif dari manajemen resiko dapat dipakai baik pada bank konvensional maupun bank syariah. Penelitian dan pengalaman selama dua dekade terakhir telah menghasilkan pemahaman yang mendalam tentang permasalahan yang berkaitan dengan manajemen resiko dan prinsip-prinsip yang terbangun dengan baik dari resiko yang dihadapi oleh manajemen.

Dalam proses manajemen resiko dapat dilakukan dengan dua langkah. Langkah pertama adalah untuk mengidentifikasi sumber resiko. Langkah kedua, adalah untuk merancang metode untuk melihat resiko dengan menggunakan model matematis. Bagi institusi Islam penting sekali memiliki manajemen resiko yang komprehensif dan proses pelaporan untuk mengidentifikasi, mengukur, memonitor, mengatur, melapor dan mengontrol kategori resiko yang berbeda.

Para pengelola perusahaan semakin menyadari pentingnya manajemen resiko. Untuk itu Dewan Pelayanan Institusi Islam, mengeluarkan dokumen standar yang komprehensif untuk manajemen resiko pada bulan Desember 2005. Dokumen ini melihat dan mendiskusikan resiko-resiko yang berbeda dan mendaftar 15 prinsipprinsip petunjuk manajemen resiko untuk institusi yang menawarkan layanan keuangan Islam.

Berikut ini beberapa jenis resiko yang terjadi pada lembaga keuangan islam;

1. Resiko-resiko Keuangan

Resiko-resiko keuangan adalah kejadian yang berefek pada kerugian keuangan langsung atas aset atau modal bank. Dalam perubahan manajemen resiko, resiko keuangan merupakan yang pertama kali muncul pada pembahasan dan pembuatan kebijakan. Baik institusi keuangan konvensional maupun Islam terancam resiko kredit dan pasar, tetapi khusus bagi institusi keuangan Islam juga terancam dengan resiko investasi atas modal sendiri. 


\section{Resiko Kredit/Pembiayaan}

Resiko kredit biasanya dikenal dengan resiko potensial yang mana pihak lawan akan gagal untuk melakukan pembayaran atas obligasinya berkaitan dengan batas waktu yang disetujui. Resiko kredit ini muncul dihampir semua instrument untuk mengubah level dan ada banyak teknik untuk meringankan resiko seperti itu. Bisnis perbankan tradisional berdasarkan pada pelaksanaan pemberian peminjaman dianggap sebagai resiko bisnis kredit karena kemampuan bank untuk meminimalisir resiko kredit adalah sumber keuntungannya. Dalam hal institusi keuangan Islam dimana pemberian pinjaman diganti dengan investasi dan kerjasama, maka pentingnya manajemen resiko kredit menjadi sangat penting.

Perbedaan yang unik dari instrumen keuangan yang dipraktekkan oleh bankbank syariah dibandingkan dengan bank-bank konvensional dalam hal resiko kredit/pembiayaan khusus sebagai berikut:

1) Pada transaksi murabahah, bank-bank syariah dihadapakan pada resiko kredit saat bank menyerahkan aset kepada klien tetapi tidak menerima pembayaran dari klien tepat pada waktunya.

2) Pada perjanjian bay' al-salam atau istisna, bank dihadapkan pada resiko kegagalan untuk mensuplai tepat waktu atau untuk mensuplai keseluruhan, atau gagal untuk mensuplai kualitas barang sebagaimana yang dinyatakan dalam kontrak. Kegagalan seperti ini akan menyebabkan penundaan atau kegagalan dalam pembayaran.

3) Pada investasi mudarabah, dimana bank syariah masuk kedalam perjanjian mudarabah sebagai pemimpin dengan mudarib luar (agen), berkaitan dengan masalah klasik antara pemimpin-agen, bank syariah dihadapkan untuk penambahan resiko kredit.

Manajemen resiko kredit/pembiayaan untuk bank syariah malah lebih rumit karena adanya faktor tambahan dari luar. Sebagai contoh adalah ketika saham bank dalam modal diinvestasikan melalui perjanjian mudarabah dan musarakah diubah menjadi obligasi utang karena kelalaian yang terbukti atau karena kesalahan mudarib. Sehingga, aturan untuk menutupi utang digunakan, yang mana aturan itu berbeda dengan aturan-aturan investasi mudarabah dan musharakah.

Teknik perhitungan resiko yang dipakai oleh bank syariah untuk resiko kredit tidak banyak berbeda dengan teknik yang dipakai oleh bank konvensional. Pengukuran resiko dapat dicapai dengan tetap menjaga data kualitas yang baik dari kinerja sebelumnya dan dengan menentukan kemungkinan kegagalan. Dibanyak negara-negara berkembang dimana tidak ada institusi formal untuk menjaga data kreit, bank sering mengandalkan catatan klien dengan bank.

Menggunakan jaminan dan penjaminan piutang sebagai tindakan keamanan terhadap resiko kredit adalah hal yang biasa dalam bank syariah. Bank bisa meminta klien untuk menempatkan jaminan tambahan sebelum melakukan transaksi murabahah. Menempatkan jaminan sebagai tindakan keamanan bukannya tanpa kesulitan, khususnya dinegara berkembang. Masalahnya termasuk, illiquiditas jaminan atau ketidakmampuan bank untuk menjual jaminan, kesulitan untuk menentukan nilai pasar yang adil dan kendala dalam mengambil kepemilikan jaminan. Karena adanya institusi legal yang lemah dan lambannya proses, menjadi sulit bagi bank untuk mengakui jaminan.

\section{Resiko Pasar}

Resiko pasar untuk institusi keuangan muncul dalam bentuk pergerakan harga yang tidak baik seperti, hasil (resiko tarif pendapatan), tarif benchmark (resiko tarif suku bunga), tarif pertukaran asing (resiko FX), modal sendiri dan harga komoditas (resiko harga) yang memiliki dampak potensial atas nilai keuangan aset. Resiko yang berkaitan dengan penguapan nilai pasar sekarang dan yang akan datang karena adanya faktor yang berbeda, adalah sebagai berikut:

1) Resiko mark-up. Bank syariah dihadapkan pada resiko mark up sebagai tarif mark up mereka yang dipakai dalam murabahah dan instrumen perdagangan 
keuangan lain ditetapkan untuk waktu kontrak ketika tarif benchmark bisa berubah.

2) Resiko harga. Pada kaitannya dengan bay'al-salam, bank syariah dihadapkan pada penguapan harga komoditas selama periode waktu antara penyerahan komoditas san penjualan komoditas.

3) Resiko nilai aset yang disewakan. Pada pelaksanaan ijarah, bank dihadapkan pada resiko market yang disebabkan oleh pengurangan nilai sisa aset yang disewakan pada akhir waktu sewa.

4) Resiko FX. Pergerakan tarif pertukaran asing adalah resiko transaksi lain yang muncul dari bentuk penangguhan perdagangan atas sejumlah kontrak yang ditawarkan oleh bank syariah.

5) Resiko perdagangan sekuritas. Dengan adanya peningkatan pasar untuk obligasi Islam (sukuk), bank syariah menginvestasikan sejumlah asetnya kedalam sekuritas pasar (sukuk). akan tetapi, harga pada sekuritas pasar seperti itu dihadapkan pada keuntungan lancar. Pasar sekunder untuk sekuritas seperti ini mungkin tidak begitu liquid dan karenanyaa bank syariah dihadapkan pada distorsi/penyimpangan harga dalam pasar liquid.

4. Resiko Investasi Modal

Beberapa bentuk resiko investasi modal, adalah:

1) Bentuk investasi modal membutuhkan penambahan monitoring untuk mengurangi informasi asimetris. Bank syariah perlu melakukan peran aktif dalam proses monitoring untuk meringankan resiko investasi modal.

2) Baik mudarabah dan musharakah adalah perjanjian pembagian untung-rugi dan dihadapkan pada kerugian modal terlepas dari monitoring yang sesuai. Tingkat resiko dalam investasi modal cukup lebih tinggi daripada pada investasi lain, karenanyaa bank syariah harus mengambil perhatian yang besar dalam mengevaluasi dan memilih proyek-proyek, untuk mengurangi potensi kerugian.

3) Investasi modal berbeda dari investasi pasar saham tidak memiliki pasar sekunder, illukuiditas investasi seperti ini dapat menyebabkan kerugian keuangan bagi bank

4) Investasi modal tidak dapat menyebabkan pendapatan tetap, dan penambahan modal bisa saja menjadi satu-satunya sumber pendapatan. Bentuk aliran tunai yang tidak terjadwal ini dapat menyebabkan kesulitan bagi bank syariah dalam menghadapi dan mengatur aliran tunai.

Prinsip IFSB atas Resiko Investasi Modal

Institusi keuangan Islam, harus menempatkan strategi yang tepat, manajemen resiko dan proses pelaporan berkaitan dengan karakteristik resiko investasi modal, termasuk investasi mudarabah dan musarakah. Institusi keuangan Islam, harus menjamin bahwa metodologi evaluasi mereka sesuai dan konsisten, dan sebaiknya menaksir dampak potensial dari metode mereka pada penghitungan dan alokasi keuntungan. Institusi keuangan Islam, harus mendefinisikan dan membangun strategi keluar berkaitan dengan aktivitas investasi modal.

5. Resiko Bisnis

Resiko bisnis diasosiasikan dengan lingkungan bisnis bank, termasuk makroekonomi dan kebijakan, faktor legal dan pengaturan, dan sector infrastruktur keuangan seperti sistem pembayaran. Resiko bisnis juga termasuk resiko menjadi insulven karena modal yang tidak cukup untuk melanjutkan operasi. Ketika institusi keuangan Islam dihadapkan pada lingkungan bisnis reguler, kesanggupan membayar, dan resiko sektor keuangan infrastruktur, sebenarnya secara khusus institusi keuangan Islam juga dihadapkan pada suatu resiko bisnis khusus, yaitu resiko tingkat pendapatan. 6. Resiko Tingkat Pendapatan.

Resiko tingkat pendapatan muncul dari ketidapastian dalam pendapatan yang dihasilkan oleh bank syariah atas aset mereka. Ketidakpastian ini dapat menyebabkan penyimpangan dari harapan pemegang jumlah investasi. Semakin besar tingkat penyimpangannya, semakin besar pula resiko tingkat pendapatan. Resiko tingkat pendapatan berbeda dengan resiko tingkat suku bunga, dalam dua hal. Pertama, karena 
bank komersial konvensional beroperasi berdasarkan pada sekutira pendapatan-suku bunga tetap, maka hanya ada sedikit ketidakpastian dalam tingkat pendapatan yang dihasilkan pada investasi mereka, jika investasinya dilakukan hingga batas tempo. Sedangkan pada bank syariah, karena memiliki gabungan antara investasi mark -up dan investasi modal sendiri, maka tingkat ketidakpastiannya lebih tinggi. Kedua, pendapatan pada deposit dalam bank konvensional, ditentukan sebelumnya. Sebaliknya, pendapatan pada deposit dalam bank syariah diperkirakan dan bukannya ditentukan. Tambahan lagi, pendapatan pada beberapa investasi yang berdasarkan kerjasama modal pada bank syariah tidak dapat diketahui secar pasto sampai akhir periode investasi. Bank syariah harus menunggu hasil investasinya untuk menentukan tingkat pendapatan investasi mereka yang akan dihasilkan oleh para depositor.

Prinsip IFSB atas Resiko Tingkat Pendapatan

Institusi keuangan Islam, harus membangun manajemen resiko dan proses pelaporan yang komprehensif untuk memperkirakan dampak potensial dari faktor pasar yang mempengaruhi tingkat pendapatan atasa aset diabndingkan dengan tingkat pendapatan yang diharapkan untuk pemegang investasi.

Institusi keuangan Islam, harus menempatkan kerangka yang sesuai untuk mengatur resiko komersial displaced, yang dapat digunakan. Institusi keuangan Islam harus menstandarkan pelaksanaan dan hak-hak pemegang investasi, yang harus secara jelas dinyatakan dan dijelaskan kepada depositor.

7. Resiko Pengambilan Uang

Jenis resiko lain dalam bisnis resiko adalah "resiko pengambilan uang". Hal ini secara umum disebabkan oleh tekanan kompetitif yang dihadapi oleh institusi keuangan Islam baik dari pihak institusi keuangan Islam yang ada, maupun dari lawannya yaitu, institusi konvensional. Bank syariah dapat dihadapkan pada resiko pengambilan uang yang dilakukan oleh para depositornya sebagai dampak dari tingkat pendapatan yang lebih rendah, jika dibandingkan dengan yang ditawarkanoleh para pesaingnya. Kompetisi seperti itu dapat berasal dari bank syariah yang lain atau dari bank konvensional tetapi dengan "Islamic window". Jika bank syariah dijalankan secara tidak efisien dan terus menghasilkan pendapatan yang lebih rendah, maka hal ini akan menentukan pada penarikan uang oleh para depositornya sehingga akan merusak nilai bank tersebut.

8. Resiko Perbendaharaan

Resiko perbendaharaan termasuk didalamnya yaitu resiko-resiko yang muncul dari manajemen sumber daya keuangan dari institusi keuangan berkaitan dengan manajemen kas, manajemen modal, manajemen liquiditas jangka pendek, dan manajemen aset dan kewajiban. Secara umum, fungsi manajemen resiko adalah bagian dari perbendaharaan institusi keuangan dan karena itu lah, ketidakmampuan apapun untuk mengatur resiko secara baik dapat menyebabkan resiko itu sendiri. Resiko perbendaharaan yang umum adalah liquiditas, resiko manajemen aset dan kewajiban, dan resiko pembatasan.

9. Resiko likuiditas

Fungsi manajemen perbendaharaan Institusi keuangan Islam menjadi tugas yang menantang karena berpengaruh pada kinerja bank syariah, sebab mudah terjadi pada resiko liquiditas. Resiko liquiditas dalam bank syariah dapat terbagi 2, yaitu kurangnya liquiditas dimana institusi keuangan dipaksa oleh aset illiquid untuk mendapat kewajiban dan obligasi keuangan. Bentuk kedua yaitu, saat dibutuhkan, bank syariah tidak memiliki akses untuk meminjam atau menaikkan dana pada biaya yang sesuai.

Dari hal-hal berikut, resiko liquiditas dapat dianggap sebagai resiko yang paling fatal yang dihadapi oleh bank syariah, yaitu:

1) Ketersediaan yang terbatas atas gabungan pasar uang syari'ah dan pasar bank intra, adalah penyebab awal resiko liquiditas. Pelarangan syari'ah untuk meminjam uang atas dasar bunga, dan ketiadaan pasar uang antar-bank, telah membatasi pilihan bagi bank syariah untuk mengatur secara efisien posisi liquiditasnya. Bank konvensional memiliki akses untuk meminjam melalui pasar antar-bank yang baik dan efisien. 
2) Pasar sekunder yang dangkal adalah sumber resiko liquiditas yang lain. Hanya ada instrumen terbatas yang dapat diperdagangkan di pasar sekunder.

3) Adanya jalan masuk bagi manajemen liquiditas yang tersedia untuk bank konvensional, yaitu pasar antar-bank, instrumen utang pasar sekunder, dianggap sebagai riba, dan karenanyaa tidak dapat diterima.

4) Beberapa karakteristik instrumen Islam juga dapat menjadi penyebab resiko liquiditas bagi bank syariah. Contohnya, resiko penundaan dalam murabahah, atau dilarangnya perjanjian perdagangan berdasarkan murabahah atau bay'alsalam karena keduanya adalah klaim keuangan dan karenanya hanya dapat diperdagangkan pada penempatan liquiditas.

5) Bank syariah memiliki jumlah dana yang agak besar dalam rekening koran yang merupakan deposit permintaan dan dapat diambil kapanpun.

Prinsip IFSB atas resiko likuiditas

Institusi keuangan Islam, harus menempatkan kerangka manajemen liquiditas. Institusi keuangan Islam, harus mengambil alih resiko liquiditas seimbang dengan kemampuannya untuk memiliki perlindungan syari'ah yang cukup untuk mengurangi resiko tersebut.

Faktor-faktor diatas telah menaikkan tekanan bagi bank syariah terhadap resiko liquiditas dan mempengaruhi kemampuan mendapat keuntungannya, dengan cara membatasi kemampuan bank syariah untuk menginvestasikan modal mereka pada aset berjangka panjang dan illiquid tapi lebih menguntungkan.

10. Resiko Manajemen Liabilitas Aset (ALM)

Resiko manajemen aset dan liabilitas adalah resiko ketidaksesuasian neraca keseimbangan yang berasal dari perbedaan tempo dan kondisi portofolio

ban atas aset dan liabilitasnya. Menurut teori, bank syariah meghadapi ketidakcocokan aset dan liabilitas yang lebih rendah, daripada pihak konvensional. Dengan mengikuit model teoritis, shock negative apapun pada pendapatan aset bank syariah, akan diserap baik oleh pemegang saham maupun investor/depositor. Para depositor pada system konvensional memiliki klaim tetap atas pendapatan asset bank ketika mereka mendapat pembayaran tarif suku bunga sebelum ditentukan.

11. Resiko Pembatasan

Resiko pembatasan adalah resiko kegagalan untuk meringankan dan mengatur berbagai jenis resiko yang berbeda. Hal ini meningkatkan resiko tekanan bank. Adanya ketiadaan produk derivativ untuk membatasi resiko, pasar sekunder yang illiquid, dan non eksisten adalah sumber-sumber lain yang meningkatkan resiko ini terhadap bank syariah.

\section{Resiko Pengaturan}

Pentingnya pengaturan dan resiko dihubungkan dengan pengaturan yang buruk telah menarik perhatian dari sejumlah peneliti dan pembuat kebijakan. Resiko pengaturan mengacu pada resiko yang muncul dari kegagalan dalam mengatur institusi, kegagalan dalam melaksanakan bisnis dan perjanjian obligasi, dan dari lemahnya lingkungan institusi exsternal maupun internal termasuk resiko resmi, dimana bank tidak mampu untuk memaksa kontrak mereka.

13. Resiko Operasional

Salah satu jenis resiko pengaturan adalah resiko operasional, didefinisikan sebagai resiko kerugian yang berasal dari ketidakcukupan atau kegagalan proses internal, berkaitan dengan masyarakat dan sistem atau dari resiko internal. Aspek-aspek yang dapat meningkatkan resiko ini didalam bank syariah termasuk:

1) Resiko penundaan dalam perjanjian non-terikat, murabahah dan istisna Kegagalan sistem kontrol internal untuk mendeteksi dan mengatur kemungkinan masalah dalam proses operasional dan resiko teknis

2) Kesulitan untuk memaksa perjanjian Islam kedalam lingkungan resmi yang lebih besar

3) Kebutuhan untuk menjaga dan mengatur komoditas inventori didalam pasar illiquid

4) Biaya dan resiko dalam memonitor perjanjian jenis modal dan resiko legal. 


\section{Resiko Penerima Kepercayaan}

Resiko kepercayaan adalah resiko yang muncul dari kegagalan institusi untuk menampilkan berkaitan dengan standar implisit dan eksplisit. Resiko ini akan menuntukkn pada resiko menghadapi tindakan perlindungan legal pada situasi dimana bank melanggar tanggung jawab penerima kepercayaanya terhadap para depositor dan pemegang saham. Berikut adalah contoh-contoh resiko penerima kepercayaan:

1) Berkaitan dengan investasi berdasarkan kerjasama dalam bentuk mudarabah dan musharakah, bank diharapkan untuk menampilkan pengawasan yang cukup atas proyek. Kelalaian dalam mengevaluasi dan memonitor proyek dapat menyebabkan terjadinya resiko terhadap penerima kepercayaan.

2) Kesalahan manajemen dana pemegang rekening koran, dapat juga menghadapkan bank pada resiko penerimaan kepercayaan.

3) Kesalahan manajemen dalam mengatur bisnis, pengalokasian biaya yang berlebihan untuk investasi rekening koran adalah pelanggaran kontrak implisit.

\section{Resiko Transparansi}

Transparansi didefiniskan sebagai "keterbukaan informasi yang dapat dipercaya yang memungkinkan pengguna informasi tersebut untuk melakukan penilaian yang akurat atas kondisi dan kinerja keuangan bank, aktivitas bisnis, tingkat resiko, dan praktek manajemen resiko. Rendahnya transparansi akan menyebabkan resiko terjadinya kerugian karena keputusan yang salah yang didasarkan pada informasi yang tidak lengkap dan tidak akurat. Bank syariah dihadapkan pada resiko transparansi karena adanya praktek non-standar penghitungand an pelaporan keuangan atas instrumen keuangan Islam, yang mana hal ini berbeda dengan instrumen konvensional.

16. Resiko Syari'ah

Resiko syari'ah berkaitan dengan struktur dan fungsi dewan syari'ah sebagai institusi dan level sistemik. Resiko ini terdiri dari dua hal, yaitu pertama, karena adanya praktek non-standar atas perjanjian yang berbeda dengan yurisdiksi yang berbeda pula. Yang kedua, karena adanya kegagalan untuk taat pada aturan syari'ah.

Ulama syari'ah telah menyatakan bahwa jika bank gagal untuk bertindak sesuai aturan syari'ah, maka transaksi tersebut harus dianggap tak berlaku dan cacat atas dasar sudut pandang syari'ah dan pendapatan yang didapat dari transaksi itu tidak boleh dimasukkan kedalam keuntungan yang akan disalurkan kepada para investor/depositor.

17. Resiko Reputasi

Resiko reputasi adalah resiko dimana kepercayaan dari klien bank syariah rusak karena adanya tindakan atau kelakuan yang tidak bertanggungjawab dari manajemen. Reputasi ini juga adalah resiko dimana hanya karena perbuatan tidak bertanggung jawab dari satu institusi dapat mencemari reputasi dari bank syariah yang lain. Publisitas yang negatif memiliki dampak yang signifikan pada saham pasar institusi, keuntungan dan liquiditas. Satu kasus kegagalan dari satu institusi dapat memberikan nama yang buruk kepada semua institusi yang mungkin saja tidak terlibat dengan tindakan tidak bertanggung jawab tersebut.

Dalam kerangka itu, tulisan ini mencoba mendiskusikan beberapa isu yang berkaitan dengan manajemen risiko perbankan syariah, baik profil risiko maupun optimalisasi peran DPS (Dewan Pengawas Syari'ah).

\section{Profil Risiko Perbankan Syariah}

Kajian manajemen risiko memang tengah naik daun. Lembaga keuangan termasuk bank syariah, setidaknya telah mengakui bahwa mereka harus memperhatikan cara-cara untuk memitigasi risiko agar bisa tetap mempertahankan daya saing, profitabilitas, dan loyalitas nasabah. Oleh karena itu bank-bank tengah berselancar pada penerapan manajemen risiko yang merupakan proses berkesinambungan serta memakan banyak pikiran, tenaga, dan uang.

Dalam konteks penerapan manajemen risiko, pedoman yang dijalankan selama ini, dibuat hanya untuk bank-bank konvensional. Padahal pemain dalam bisnis perbankan dunia dan nasional tidak hanya bank konvensional, tetapi juga telah 
diramaikan oleh bank dengan prinsip syariah yang jumlahnya terus meningkat dari tahun ke tahun. Maka bagaimana penerapan manajemen risiko pada bank-bank syariah?

Secara historis penerapan manajemen risiko pada bank, dalam hal ini BI sendiri baru mulai menerapkan aturan perhitungan capital adequacy ratio (CAR) pada bank sejak 1992. Sementara itu, bank dengan prinsip syariah lahir pertama kali di Indonesia pada tahun yang sama. Jadi jika dilihat dari usia sistem perbankan syariah, hal ini merupakan tantangan yang berat. Bank syariahpun akan sangat sulit mengikuti konsep yang telah dijalankan perbankan konvensional dalam hal manajemen risiko, mengingat perbankan konvensional membutuhkan waktu yang panjang untuk membangun sistem dan mengembangkan teknik manajemen risiko .

Di Lain pihak, operasi bank syariah memiliki karakteristik dengan perbedaan yang sangat mendasar jika dibandingkan dengan bank konvensional, sementara manajemen risiko juga harus diimplementasikan oleh bank syariah agar tidak hancur dihantam risiko. Oleh karena itu, apa yang dapat dilakukan? Cara yang paling cepat dan efektif adalah mengadopsi sistem manajemen risiko bank konvesional yang disesuaikan dengan karakteristik perbankan syariah. Inilah yang dilakukan BI sebagai regulator perbankan nasional yang akan menerapkan juga bagi perbankan syariah.

Dalam hal ini Islamic Financial Services Board (IFSB), telah merumuskan prinsip-prinsip manajemen risiko bagi bank dan lembaga keuangan dengan prinsip syariah. Pada 15 Maret 2005 yang lalu, exposure draft yang pertama telah dipublikasikan. Dalam executive summary draft tersebut dengan jelas disebutkan bahwa kerangka manajemen risiko lembaga keuangan syariah mengacu pada Basel Accord II (yang juga diterapkan perbankan konvensional) dan disesuaikan dengan karakteristik lembaga keuangan dengan prinsip syariah.

Secara umum, risiko yang dihadapi perbankan syariah bisa diklasifikasikan menjadi dua bagian besar. Yakni risiko yang sama dengan yang dihadapi bank konvensional dan risiko yang memiliki keunikan tersendiri karena harus mengikuti prinsip-prinsip syariah. Risiko kredit, risiko pasar, risiko benchmark, risiko operasional, risiko likuiditas, dan risiko hukum, harus dihadapi bank syariah. Tetapi, karena harus mematuhi aturan syariah, risiko-risiko yang dihadapi bank syariah pun menjadi berbeda.

Bank syariah juga harus menghadapi risiko-risiko lain yang unik (khas). Risiko unik ini muncul karena isi neraca bank syariah yang berbeda dengan bank konvensional. Dalam hal ini pola bagi hasil (profit and loss sharing) yang dilakukan bank syari'ah menambah kemungkinan munculnya risiko-risiko lain. Seperti withdrawal risk, fiduciary risk, dan displaced commercial risk merupakan contoh risiko unik yang harus dihadapi bank syariah. Karakteristik ini bersama-sama dengan variasi model pembiayaan dan kepatuhan pada prinsip-prinsip syariah.

Konsekuensinya, teknik-teknik yang digunakan untuk melakukan identifikasi, pengukuran, dan pengelolaan risiko pada bank syariah dibedakan menjadi dua jenis. Teknik-teknik standar yang digunakan bank konvesional, asalkan tidak bertentangan dengan prinsip syariah, bisa diterapkan pada bank syariah. Beberapa di antaranya, GAP analysis, maturity matching, internal rating system, dan risk adjusted return on capital (RAROC).

Di sisi lain bank syariah bisa mengembangkan teknik baru yang harus konsisten dengan prinsip-prinsip syariah. Ini semua dilakukan dengan harapan bisa mengantisipasi risiko-risiko lain yang sifatnya unik tersebut. Survei yang dilakukan Islamic Development Bank (2001) terhadap 17 lembaga keuangan syariah dari 10 negara mengimplikasikan, risiko-risiko unik yang harus dihadapi bank syariah lebih serius mengancam kelangsungan usaha bank syariah dibandingkan dengan risiko yang dihadapi bank konvesional. Survei tersebut juga mengimplikasikan bahwa para nasabah bank syariah berpotensi menarik simpanan mereka jika bank syariah memberikan hasil yang lebih rendah daripada bunga bank konvesional. Lebih jauh survei tersebut menyatakan, model pembiayaaan bagi hasil, seperti diminishing musyarakah, musyarakah, mudharabah, dan model jual-beli, seperti salam dan istishna', lebih berisiko ketimbang murabahah dan ijarah. 
Dalam pengembangannya ke depan, perbankan syariah menghadapi tantangan yang tidak ringan sehubungan dengan penerapan manajemen risiko ini seperti, pemilihan instrumen finansial yang sesuai dengan prinsip syariah termasuk juga instrumen pasar uang yang bisa digunakan untuk melakukan hedging (lindung nilai ) terhadap risiko. Oleh karena BI dan IFSB mengacu pada aturan Basel Accord II, maka pemahaman yang matang mengenai manajemen risiko bank konvensional akan sangat membantu penerapan manajemen risiko di bank syariah.

\section{Optimalisasi Peran Dewan Pengawas Syari’ah}

Dewan Pengawas Syari'ah (DPS) memiliki peran penting dan strategis dalam penerapan prinsip syariah di perbankan syari'ah. DPS bertanggung jawab untuk memastikan semua produk dan prosedur bank syariah sesuai dengan prinsip syariah. Karena pentingnya peran DPS tersebut, maka dua Undang-Undang di Indonesia mencantumkan keharusan adanya DPS tersebut di perusahaan syariah dan lembaga perbankan syariah, yaitu Undang-Undang UU No. 40 Tahun 2007 tentang Perseroan Terbatas dan UU No. 21 Tahun 2008 tentang Perbankan Syariah. Dengan demikian secara yuridis, DPS di lembaga perbankan menduduki posisi yang kuat, karena keberadaannya sangat penting dan strategis.

Berdasarkan Undang-Undang tersebut, setiap perusahaan yang berbadan hukum Perseroan Terbatas wajib mempunyai Dewan Pengawas Syariah. Sejalan dengan itu, Undang-Undang No 21 Tahun 2008 tentang perbankan syari'ah, pasal 32 menegaskan hal yang sama. Berdasarkan kedua Undang-Undang tersebut kedudukan DPS sudah jelas dan mantap serta sangat menentukan pengembangan bank syariah dan perusahaan syariah di masa kini dan masa mendatang. Tetapi peran DPS tersebut belum optimal dalam menjalankan pengawasan syari'ah terhadap operasional perbankan syariah. sehingga berakibat pada pelanggaran syariah complience, maka citra dan kredibilitas bank syariah di mata masyarakat bisa menjadi negatif, sehingga dapat menurunkan kepercayaan masyarakat kepada bank syariah bersangkutan.

Menurut hasil penelitian Bank Indonesia (2008) kerjasama dengan Ernst dan Young yang dibahas dalam seminar akhir tahun 2008 di Bank Indonesia, salah satu masalah utama dalam implementasi manajemen risiko di perbankan syariah adalah peran DPS yang belum optimal. Pernyataan itu disimpulkan para peneliti sebagai kesenjangan utama manajemen risiko yang harus diperbaiki di masa depan.

Jenis manajemen risiko yang terkait erat dengan peran DPS adalah risiko reputasi yang selanjutnya berdampak pada displaced commercial risk, seperti risiko likuiditas dan risiko lainnya. Shanin A.Shayan CEO and Board Member of Barakat Foundation menyatakan bahwa, risiko terbesar menghadapi system keuangan global bukanlah kesalahan tentang kemampuan menciptakan laba, tetapi yang lebih penting adalah kehilangan kepercayaan dan kredibiliatas tentang bagaimana operasional kerjanya.

Oleh karena itu peran DPS perlu dioptimalkan, agar mereka bisa memastikan segala produk dan sistem operasinal bank syariah benar-benar sesuai syariah. Untuk memastikan setiap transaksi sesuai dengan syari'ah, anggota DPS harus memahami ilmu ekonomi dan perbankan dan berpengalaman luas di bidang hukum Islam. Dengan demikian kualifikasi menjadi anggota DPS harus memahami ilmu ekonomi dan keuangan serta perbankan serta expert di bidang syariah.

Namun sangat disayangkan, masih terdapat DPS yang belum memahami ilmu ekonomi keuangan dan perbankan. Selain itu mereka juga masih banyak yang tidak melakukan supervisi dan pemeriksaan akad-akad yang ada di perbankan syariah. Padahal menurut ketentuannya, DPS bekerja secara independen dan bebas untuk meninjau dan menganalisa pada semua kontrak dan transaksi.

Mengacu pada kualifikasi DPS tersebut di atas, maka bank-bank syariah di Indonesia perlu melakukan restrukturisasi, perbaikan dan perubahan ke arah yang lebih baik dan mengangkat DPS dari kalangan ilmuwan ekonomi Islam yang berkompeten di bidangnya. Hal ini mutlak perlu dilakukan agar perannya bisa optimal dan menimbulkan citra positif bagi pengembangan bank syariah di Indonesia 
Pengalaman selama ini, bank-bank syariah di Indonesia mengangkat DPS, yakni orang yang sangat terkenal di ormas Islam atau terkenal dalam ilmu keislaman (bukan syariah), tetapi tidak berkompeten dalam bidang perbankan dan keuangan syariah. Realitas ini di satu sisi menguntungkan bagi manajemen perbankan syariah, karena mereka lebih bebas berbuat apa saja, karena pengawasannya sangat longgar.

Tetapi dalam jangka panjang hal ini justru merugikan gerakan ekonomi syariah, tidak saja bagi bank syariah bersangkutan tetapi juga bagi gerakan ekonomi dan bank syariah secara keseluruhan dan kemajuan bank syariah di masa depan. Karena itu, tidak aneh jika banyak masyarakat yang memandang bahwa bank syariah sama dengan bank konvensional.

Tetapi harus diakui, bahwa sebagian DPS bank syariah sudah berperan secara optimal, meskipun masih lebih banyak yang belum optimal. Inilah yang harus ditangani Bank Indonesia, DSN MUI dan bank-bank syariah sendiri. Oleh karena itu, UU yang memposisikan DPS yang demikian strategis, harus diimplementasikan dengan tepat dan cepat. Untuk itu setiap manajemen bank syariah harus melakukan formalisasi peran dan keterlibatan DPS dalam memastikan pengelolaan risiko ketidakpatuhan atas peraturan dan prinsip syariah.

\section{Penutup}

Dari paparan di atas dapat diambil kesimpulan sebagai berikut:

1. Kapasitas manajemen risiko yang efisien adalah bagaimana bank syariah mampu menempatkan posisi secara strategis dalam pasar global dengan mereduksi semua risiko. Tidak adanya sistem manajemen risiko yang sehat dan kuat dapat menghilangkan bank syariah dari kemampuannya dalam mengatasi risiko, dan dapat mengurangi kontribusi potensialnya.

2. Sumber daya yang memadai perlu dicurahkan untuk pengukuran dan identifikasi risiko serta pengembangan teknik-teknik manajemen risiko. Dalam hal ini, ada kebutuhan yang mendesak untuk mengkombinasikan pemahaman hukum syariah yang solid dengan pengetahuan teknik manajemen risiko modern yang kuat sehingga mampu mengembangkan mitigasi risiko yang inovatif.

3. Fungsi dan peran DPS di bank syariah, memiliki relevansi yang kuat dengan manajemen risiko perbankan syariah, yakni risiko reputasi, yang selanjutnya berdampak pada risiko lainnya seperti risiko likuiditas. Pelanggaran syariah complience yang dibiarkan atau luput dari pengawasan DPS, akan merusak citra dan kredibilitas bank syariah di mata masyarakat, sehingga dapat menurunkan kepercayaan masyarakat kepada bank syariah bersangkutan. Untuk itulah peran DPS di bank syariah harus benar-benar dioptimalkan, kualifikasi menjadi DPS harus diperketat, dan formalisasi perannya harus diwujudkan di bank syariah tersebut.

\section{DAFTAR PUSTAKA}

Afriyeni, A., \& Marlius, D. (2019). Analisis Tingkat Pengembalian Dan Risiko Investasi (Studi Pada Industri Manufaktur Yang Terdaftar Di Bursa Efek Indonesia). https://doi.org/10.31219/osf.io/cfb92

Agustianto, Evaluasi Bank Syari'ah 2008 dan Outlook Bank Syari'ah 2008.

Antonio, H. Muhammad Syafei. Bank Syariah : Dari Teori ke Praktek. Gema Insani Press. Jakarta. 2001

Perwataatmadja, Karnaen. Apa Dan Bagaimana Bank Islam. Penerbit PT. Dana Bhakti Prima Yasa. Yogyakarta. 1999

Bank Indonesia, 2008. 
Greuning, H. and S. Bratanovic (2003), "Analyzing and Managing Banking Risk: A Framework for Assessing Corporate Governance and Financial Risk”, (2nd edition). World Bank Publication.

Khan \& Ahmed (2001), "Risk Management: An Analysis of Issues in Islamic Financial Industry”. Occasional Paper no. 5. Islamic Research and Training Institute: Islamic Development Bank

Meidisa, C., \& Susanti, F. (2019). Pengaruh Preferensi Dan Pengetahuan Produk Terhadap Minat Menabung Masyarakat Pada Bank Nagari Unit Layanan Syariah Cabang Pasar Raya Padang. https://doi.org/10.31227/osf.io/bf7cr

Mulia, T., \& Afriyeni, A. (2019). Penerapan Manajemen Risiko Operasional Pada Unit Teller PT. Bank Pembangunan Daerah Sumatera Barat. https://doi.org/10.31219/osf.io/w5uqk

Prasetyo, Z., \& Afriyeni, A. (2019). Penerapan Manajemen Resiko Operasional Pada PT. Bank Pembangunan Daerah Sumatera Barat Cabang Painan Kabupaten Pesisir Selatan. https://doi.org/10.31219/osf.io/83ea4

Sjahdeini, Sutan Remy. Perbankan Islam dan Kedudukannya Dalam Tata Hukum Perbankan Indonesia. Cetakan I. Penerbit PT. Pustaka utama Grafiti. Jakarta. 1999.

Sri Susilo, Y. Dkk. Bank dan Lembaga Keuangan Lain. Penerbit Salemba Empat. Jakarta. 2000.

Tedy Fardiansyah Idris, Tantangan Manajemen Risiko Bank Syari'ah, dikutip dari InfoBankNews.com

Tariqullah Khan dan Habib Ahmed, Manajemen Risiko Lembaga Keuangan Syariah, penerjemah dan pengantar Ikhwan Abidin Basri, (Jakarta: Bumi Aksara, 2008).

Undang-undang Nomor 40 tahun 2007 tentang Perseroan Terbatas.

Undang-undang Nomer 21 tahun 2008 tentang Perbankan Syari'ah.

Wulandari, R., \& Susanto, R. (2019). Penerapan Manajemen Risiko Operasional Pada Unit Teller Pada PT. Bank Pembangunan Daerah Sumatera Barat Cabang Lubuk Alung. https://doi.org/10.31219/osf.io/pjgch 